\title{
Frequency of change of chlorhexidine-impregnated gel dressings for central venous catheters in critically ill patients ${ }^{a}$
}

\author{
Tempo de permanência do curativo gel de clorexidina no cateter venoso central em paciente crítico \\ Tiempo de permanencia del apósito gel de clorhexidina en catéter venoso central en paciente crítico
}

\author{
Mariana Ehmke Dolci ${ }^{1}$ \\ Amanda Salles Margatho ${ }^{2}$ \\ Renata Cristina de Campos Pereira Silveira ${ }^{1}$
}

1. Universidade de São Paulo.

Ribeirão Preto, São Paulo, Brazil.

2. Universidade Estadual de Londrina.

Londrina, Paraná, Brazil.

\begin{abstract}
Objectives: To identify the frequency of change of chlorhexidine-impregnated gel dressings applied in central venous catheter insertion sites, describe reasons for dressing changes, and identify the amount of dressings used per adult patients admitted to an intensive care unit. Methods: Descriptive study consisting of daily record of occurrence evaluation, reason for dressing change and quantity used per patient, between April and December 2014. Descriptive statistical analysis was used. Results: A total of 159 dressings were applied at the insertion site of 64 central venous catheters whose mean frequency of dressing changes was 3.04 days. The mean number of dressing per patient was 3.1, but 83 unscheduled changes occurred before 7 days of stay, due to detachment, wetness, soiling, and loss of dressing. Conclusion: The frequency of dressing changes was less than seven days, resulting in greater quantities of dressings per patient. Detachment was the most common reason for unscheduled dressing changes.
\end{abstract}

Keywords: Intensive Care Units; Central Venous Catheters; Occlusive Dressings; Chlorexidine; Nursing Care.

\section{Resumo}

Objetivos: Identificar o tempo de permanência do curativo gel de clorexidina aplicado no sítio de inserção do cateter venoso central, descrever motivos de troca e identificar a quantidade utilizada por paciente adulto internado em unidade de terapia intensiva. Métodos: Estudo descritivo consistindo de registro diário de avaliação de ocorrência, motivo da troca de curativo e quantidade usada pelo paciente, entre abril e dezembro de 2014. Utilizou análise estatística descritiva. Resultados: Aplicou-se 159 curativos no sítio de inserção de 64 cateteres venosos centrais cujo tempo médio de permanência foi de 3,04 dias. A média de curativo por paciente foi de 3,1, mas ocorreram 83 trocas não programadas, antes de sete dias de permanência, por descolamento, umidade, sujidade e perdas. Conclusão: A permanência do curativo foi inferior a sete dias acarretando um número maior de curativo utilizado por paciente. $O$ descolamento do curativo foi o motivo mais frequente de troca não programada.

Palavras-chave: Unidades de Terapia Intensiva; Cateteres Venosos Centrais; Curativos Oclusivos; Clorexidina; Cuidados de Enfermagem.

\section{Resumen}

Objetivos: Identificar el tiempo de permanencia del apósito gel de clorhexidina aplicado en sitio de inserción del catéter venoso central, describir razones del cambio e identificar cantidad de apósitos utilizados por paciente adulto internado en unidad de terapia intensiva. Métodos: Estudio descriptivo consistente en registro diario de evaluación de ocurrencia, motivo del cambio de apósito y cantidad utilizada por paciente, de abril a diciembre de 2014. Análisis por estadística descriptiva. Resultados: Se aplicaron 159 apósitos en sitio de inserción de 64 catéteres venosos centrales, con tiempo medio de permanencia de 3.04 días. El promedio de apósitos por paciente fue 3.1, aunque ocurrieron 83 cambios no programados, previos a siete días de permanencia, por despegado, humedad, suciedad y pérdida del apósito. Conclusión: La permanencia del apósito fue inferior a siete días, determinando mayor número de apósitos utilizados por paciente. El despegado del apósito fue el motivo prevalente de cambio no programado.

Palabras clave:Unidades de Cuidados Intensivos; Catéteres Venosos Centrales; Apósitos Oclusivos; Clorhexidina; Atención de Enfermería.
Corresponding author: Mariana Ehmke Dolci.

E-mail: marianadolci@gmail.com

Submitted on $02 / 18 / 2017$.

Accepted on 07/19/2017.

DOI: 10.1590/2177-9465-EAN-2017-0026 


\section{INTRODUCTION}

Critically ill patients are patients who require continuous surveillance and high complexity care; they are usually admitted to intensive care units (ICUs). ${ }^{1}$ In view of the instability of these patients, the use of the central venous catheters (CVCs) is indispensable for the management of their therapy; therefore they are considered an essential device, widely used in ICUs. ${ }^{2-4}$

A CVC is defined as an intravascular access; its tip is located near or inside the right atrium or one of its great vessels. ${ }^{4}$ This device has a series of purposes, including: blood collection; continuous or intermittent infusions of intravenous solutions; administration of blood components and blood products; parenteral nutrition; administration of medicinal products that cannot be administered peripherally; and estimating values of central venous pressure..$^{2,5,6}$

Despite its benefits, the use of short-term CVCs is associated with infectious complications that may increase hospital-related costs and lead to longer hospital stays. ${ }^{2-5}$ It is important to mention that the main pathogenic mechanism of this type of infection occurs due to loss of skin integrity, caused by the insertion of the intravascular catheter; therefore migration of skin microorganisms around the insertion site to its tip may occur. ${ }^{3,5,7}$

Considering that catheter-related infections are associated with increased morbidity and mortality of patients using intravascular devices and hospital-related costs, prevention and control measures are recommended and adopted aiming at mitigating these issues. ${ }^{5,8,9}$ One of these measures is the use of occlusive dressings at the CVC insertion site. An ideal dressing must be able to prevent infections, properly fix the catheter, provide comfort, avoid skin irritations, and be easily applied and cost effective..$^{3,9-12}$

There have been discussions on whether skin antisepsis with chlorhexidine-alcohol alone performed during the insertion of intravascular devices and in CVC dressings is sufficient to prevent and control skin colonization around the insertion site and, consequently, intravascular catheter-related infections. ${ }^{9,11}$ The literature evidenced the presence of remaining bacteria that may colonize the CVC even after this antisepsis process. ${ }^{5,9,11}$ Therefore the importance of the use of chlorhexidine-impregnated dressings is emphasized.

In 2011 the Centers for Disease Control and Prevention (CDC) recommended the use of chlorhexidine-impregnated dressings for sites where catheter-related bloodstream infection presents no reduction, even after the implementation of basic measures to prevent these infections, such as education and training of the team, use of maximum protection barrier, and use of chlorhexidine for skin antisepsis at the CVC insertion site. ${ }^{5}$

Analysis of a systematic review with meta-analysis of nine clinical randomized trials concluded that chlorhexidine-impregnated gel dressings reduce the incidence of catheter-related bloodstream infections and the colonization of several catheter types; thus the use of these dressings is recommended, and the need for further studies with this type of dressing exclusively in central catheters is suggested. ${ }^{9}$

Chlorhexidine-impregnated gel dressings offer rapid, effective antimicrobial activity; they are made up of a transparent polyurethane film and have a hydrogel that continuously releases chlorhexidine at $2 \% .^{9,11,12}$ According to recommendations found in the literature and by manufacturers these dressings should be changed every seven days, and unscheduled changes should be carried out before this period when the dressing presents wetness, detachment, and/or exudates surpassing the margins of the gel or preventing the visualization of the insertion site. ${ }^{13-16}$

Studies showed that unscheduled changes are common events in patients admitted to ICUs, and that they are related to the increased number of catheter-related infections. ${ }^{16-18}$ Therefore adequate CVC dressing management is a strategy to prevent such infections. $8,17,19$

Dressings used as a CVC cover represent an important measure to reduce catheter-related infections. Since the nursing staff is responsible for choosing the type of coverage, ${ }^{19}$ an understanding on the aspects related to their use is essential so that nursing professionals may perform the assessment, indication, and maintenance of these dressings, contributing to the safety of patients using CVCs.

The aim of the present study was to identify the frequency of change of chlorhexidine-impregnated gel dressings applied at the insertion sites of central venous catheters, describe the reasons for the changes, and identify the quantity of devices used per adult patient admitted to an intensive care unit.

\section{METHODS}

A quantitative study, with a descriptive approach, was conducted to analyze the use of chlorhexidine-impregnated gel dressings in critically ill patients. This study is focused on a clinical randomized trial, ${ }^{20}$ and the data used were obtained from participants in an experimental group.

The study was conducted in the ICU of a high complexity teaching hospital in the state of São Paulo. As eligibility criteria, the present study included patients aged over 18 years with short-term CVC, and using chlorhexidine-impregnated gel dressings.

The participants were recruited by the researchers responsible for data collection upon confirmation that the patient met the inclusion criteria. Once the eligibility criteria were met, the patient or their legal representative (if the patient had no condition to express their acceptance due to clinical factors, sedation, or unconsciousness) was informed about the study characteristics, and their consent was requested.

Considering that the proposal was to assess a technology that had not yet been incorporated in the clinical practice of the unit, the training of nursing aides to use chlorhexidine-impregnated gel dressings was proposed. All the thirteen nurses of the ICU authorized and signed the free and informed consent form to participate in the training and data collection. 
Chlorhexidine-impregnated gel dressings are manufactured by the company $3 \mathrm{M}^{\circledR}$, type 1657 (code of the manufacturer), consisting in a transparent $8.5 \mathrm{~cm} \mathrm{X} 11.5 \mathrm{~cm}$ sterile film with translucent gel impregnated with $2 \%$ chlorhexidine gluconate in its central portion, with an area of $3 \mathrm{~cm} \times 4 \mathrm{~cm}$, adhesive margins made of polyester fabric peripherally to the slotted transparent film, and two adhesive tapes independent of the dressing to stabilize the catheter.

The training for using chlorhexidine-impregnated gel dressings consisted in a 20-minute theoretical class with audiovisual resources addressing: physical-chemical properties of the dressings; cost; start time and indications of use; skin preparation; solution used for antisepsis; how to apply the dressings; time of use; daily assessment of the dressing; and indication and how to remove the dressing. Application and removal of dressing were demonstrated on a mannequin with a CVC.

The nurses undertook a test, and the training was repeated until all of them achieved a score of $100 \%$.

During the first 24 hours after the insertion of the CVC until the local bleeding is ceased, all patients used sterile gauze fixed with an adhesive tape as a dressing, a measured recommended by the CDC. The following dressings consisted in chlorhexidine-impregnated gel dressings, with changes carried out according to recommendations found in the literature. ${ }^{5}$ Changes after seven days of use of the dressing were classified as scheduled changes, and those before this period were classified as unscheduled changes.

In the ICU where the study was conducted, the following CVC-related infection prevention measures were established: use of maximum protection barrier (use of mask, cap, long-sleeve sterile gown, sterile gloves, and sterile fields) and chlorhexidinealcohol at $0.5 \%$ for skin antisepsis at the CVC insertion site, as well as daily bath of patients with antibacterial chlorhexidine at $2 \%$. Data collection was carried out using a collection instrument that was previously submitted to face and content assessment by five experts; all of them were nurses: three worked in the clinical practice of the intensive care unit and two were professors working in the academic area. The following variables were included after this assessment: age, gender, apache II, length of stay, catheter type, insertion site, frequency of change of the catheter, reason for removal of the catheter, frequency of change of the chlorhexidine-impregnated gel dressing, dressing change, reason for changing the chlorhexidine-impregnated gel dressing, and quantity of chlorhexidine-impregnated gel dressing used per patient.

Data were collected on a daily basis between April and December 2014. The researchers assessed the dressing and, when the dressing had been changed, they verified the reason for the change in the data collection instrument of the patient.

The statistical analysis of the variables was descriptive through the use of the software IBM SPSS version 24.0 for Windows.
The present study involves a new project approaching different objectives from the clinical randomized trial, thus it was separately submitted and approved by the Research Ethics Committee of the Ribeirão Preto College of Nursing at the University of São Paulo under normative instruction 1.835 .765 and protocol CAAE 56574716.8.0000.5393 and CAAE: 20121613.2.0000.5393.

\section{RESULTS}

According to the eligibility criteria, 52 patients met the inclusion criteria for analysis of use of chlorhexidine-impregnated gel dressings. Data related to sociodemographic and clinical variables of these patients are presented in Table 1.

Table 1. Distribution of patients $(n=52)$ using chlorhexidine-impregnated gel dressings in the central venous catheter according to sociodemographic and clinical characteristics. Ribeirão Preto-SP, 2014

\begin{tabular}{lll}
\hline Variable & \% & N \\
\hline Gender & & \\
\hline Male & 60 & 31 \\
Female & 40 & 21 \\
\hline Age (full years) & & \\
\hline $18-39$ & 13 & 07 \\
$40-49$ & 16 & 08 \\
$50-59$ & 13 & 07 \\
$>60$ & 58 & 30 \\
\hline APACHE II & & \\
\hline $9-10$ & 04 & 02 \\
$11-20$ & 17 & 09 \\
$21-30$ & 46 & 24 \\
$31-43$ & 33 & 17 \\
\hline Length of stay & & \\
\hline $1-10$ days & 63 & 33 \\
$11-20$ days & 25 & 13 \\
$21-50$ days & 12 & 06 \\
\hline
\end{tabular}

Source: Data obtained in the study.

The mean age of the patients was 57.9 years, with a standard deviation of 15.488 . The severity of the patients admitted to the ICU was calculated by the researcher during the first 24 hours of hospitalization in the unit through the APACHE II score. The mean score was 26.6 with a standard deviation of 8.428 . The mean length of stay of the patients in the unit was 10.96 days with a standard deviation of 10.261 .

Some patients of the present study presented suspicion of CVC-related infection, so their catheters were removed. In other patients, accidental traction of the catheter occurred, and due to 
the need for maintaining an intravascular access, these patients were submitted to a new catheterization. Of the 52 recruited patients, 6 individuals underwent the insertion of a second CVC, in five a third CVC was placed, and only one presented a fourth catheter. Thus, this study analyzed 64 catheters. Data related to these catheters are presented in Table 2.

Table 2. Distribution of central venous catheters $(n=$ 64) of patients using chlorhexidine-impregnated gel dressings according to type, insertion site, and reason for removal. Ribeirão Preto-SP, 2014

\begin{tabular}{lll}
\hline Variable & \% & N \\
\hline Type of CVC* & & \\
\hline Double lumen & 86 & 55 \\
Triple lumen & 14 & 09 \\
\hline CVC* insertion site & & \\
\hline Jugular vein & 47 & 30 \\
Subclavian vein & 47 & 30 \\
Femoral vein & 06 & 04 \\
\hline Reason for removal of the CVC* & & \\
\hline Death & 33 & 21 \\
End of indication for use & 31 & 20 \\
Suspicion of infection & 30 & 19 \\
Accidental traction of the catheter & 03 & 02 \\
Misplacement & 03 & 02 \\
\hline
\end{tabular}

Source: Data obtained in the study. * CVC: Central Venous Catheter.

Table 2 shows the same distribution of catheters in the subclavian and jugular veins; the minority was inserted into a femoral vein access. Double lumen was the predominant catheter type. The mean time of permanence of the CVC was 8.6 days, with a standard deviation of 4.97 ; the minimum period of use of 2 and the maximum 23 days. The main reason for removal of the CVC was patient death.

Considering that all the used dressings consisted in chlorhexidine-impregnated gel dressings and that these were applied 24 hours after the insertion of the CVC, the total was 159 dressings used in all the catheters. The mean number of dressings used per patient was 3.1 (minimum of 1 and maximum of 16 dressings), with a standard deviation of 3.233.

Of the 159 used dressings, $25.8 \%$ (41) were kept at the CVC insertion site of the patient for one day, $23.3 \%$ (37) were kept (no need to change) for two days, $17 \%$ (27) for three days, $13.2 \%$ (21) for four days, $6.3 \%$ (10) for five days, $4.4 \%$ (7) for six days, and $10.1 \%$ (16) for seven days. The mean frequency of change of the dressings was 3.04 days $(\mathrm{sd}=1.917)$.

The reasons for unscheduled changes were classified as follows: wet dressing (wet or moist dressing); soiled dressing (saturated dressing or presenting stains/dirt that prevented the visualization of the output site, or with exudate exceeding the margins of the gel, or presence of feces in the dressing); loosen dressing (dressing with the fixation borders loosen, or presence of air bubbles in the chlorhexidine gel); loss of the dressing (change due to interruption of CVC use, or in cases where catheter traction was necessary, or in cases of accidental traction of the catheter).

A total of 95 changes occurred among the 159 utilized dressings, as among the 64 CVCs 25 were applied in a single dressing, without replacement of the dressing, and in 39 catheters there was no need to apply a new dressing after removal of the last one, considering the interruption of use of the catheter by the patient. Of these changes, $87 \%$ (83) were unscheduled and $13 \%$ (12) were scheduled changes. Unscheduled changes were more frequent in the subclavian vein, and the most common reason was detachment of the dressing (Table 3).

\section{DISCUSSION}

The main objective of the present study was to evaluate the time of permanence of chlorhexidine-impregnated gel dressings as their use has been studied, particularly in the international literature, and their effectiveness has been suggested in view of a significant reduction in catheter colonization and infections related to this device. ${ }^{3,6,9,16}$

It is important to describe the reasons for unscheduled dressing changes as they represent events that may be associated with an increased number of catheter-related infections. ${ }^{16-18}$

There was a predominance of male patients among the participants of this study, and the mean age was 57.9 years. These data are similar to the characteristics of patients admitted in other ICUs of the country, where a predominance of male patients and mean age of 53.69 years, 55.8 years, and 60.0 years was observed. ${ }^{21-23}$ Population aging in the country, resulting in an increased number of individuals with noncommunicable chronic diseases, leads to a higher level of vulnerability of older age groups and increases morbidity and the frequency of hospitalizations of elderly individuals. ${ }^{24}$

The mean APACHE II score of the patients of the present study was 26.6 and the mean length of stay in the ICU was 10.96 days. A study conducted in another ICU of the state of São Paulo found a mean APACHE II score of 10.2 and length of stay of 4.3 days. ${ }^{21}$ It is noteworthy that the higher the level of severity of the patient, the higher their level of dependence and length of stay in the intensive care unit. ${ }^{21,25}$

High levels of severity increase the risk of healthcareassociated infections because patients are unstable, require invasive procedures, present longer length of stay in the ICU, and require insertion of multiple catheters and excessive manipulation of $\mathrm{CVC}$ lines. ${ }^{25}$

A multicenter study evidenced that dressing disruption is a common event in ICUs. ${ }^{17}$ This study assessed 1,419 patients in a clinical randomized trial, analyzed 11,036 catheter 
Table 3. Distribution of unscheduled changes $(n=83)$ of chlorhexidine-impregnated gel dressings according to central venous catheter insertion site. Ribeirão Preto-SP, 2014

\begin{tabular}{lccccc}
\hline \multirow{2}{*}{ CVC*insertion site } & \multicolumn{4}{c}{ Reasons for unscheduled change } & \\
& Detachment \% (n) & Soiling \% (n) & Dressing loss \% (n) & Wetness \% (n) & Total \% (n) \\
\hline Subclavian vein & $24(20)$ & $18(15)$ & $05(4)$ & $02(2)$ & $49(41)$ \\
Jugular vein & $23(19)$ & $15(12)$ & $0(0)$ & $0(0)$ & $38(31)$ \\
Femoral vein & $05(4)$ & $08(7)$ & $0(0)$ & $0(0)$ & $13(11)$ \\
\hline Total & $52(43)$ & $41(34)$ & $05(4)$ & $02(2)$ & $100(83)$ \\
\hline
\end{tabular}

Source: Data obtained in the study. ${ }^{*}$ CVCs: Central Venous Catheters.

dressing changes, and showed that $67 \%$ of these changes were nonstandardized. Such changes occurred with higher frequency in patients with high scores of severity. ${ }^{17}$

The catheters of the present study were removed when there was no more indication of use, due to death of the patient, when there was suspicion of infection related to this device, when traction of the catheter occurred, or when it was not properly positioned by traction on the catheter. In this study 12 new catheters were punctured in the cases that required maintenance of intravenous therapy in CVCs.

According to recommendations of the Centers for Disease Control and Prevention (CDC, 2011), CVCs should not be changed periodically to reduce the number of catheter-related infections without the occurrence of signs and symptoms of infection. Therefore, there is no need to replace a functioning catheter to minimize complications related to the insertion procedure and time of permanence of the device, such as pneumothorax, hemothorax, thrombosis, and laceration of the insertion vein. ${ }^{5}$

The CVCs remained in situ for an average period of 8.6 days, a fact that may be considered as a risk factor for catheter colonization. ${ }^{26}$ The higher the time of use of the CVC, the higher the risk of catheter-related infection. ${ }^{3,5,19,26}$ It is important to mention that the mean time of permanence of the CVCs observed in the present study was higher than the values described in the literature. A national randomized clinical trial described a mean frequency of change of 4.9 days in the intervention group (chlorhexidine-impregnated gel dressing) and 5 days in the control group (transparent polyurethane film). ${ }^{27}$ International studies point out mean times of 6 days of use of the catheters. ${ }^{15,16}$

Among the reasons for removal of CVCs in the present study, 30\% (19) occurred due to suspicion of infection related to the intravascular catheter, even when using chlorhexidineimpregnated gel dressings. This result was compared to a meta-analysis that included nine randomized clinical trials and assessed 6,067 patients with 11,214 CVCs: 5,586 used chlorhexidine-impregnated gel dressings and 5,628 used transparent polyurethane film. The results showed that chlorhexidine dressings reduce the incidence of catheter-related bloodstream infections ( $p=0.002$ and IC 95\% 0.42-0.79). ${ }^{9}$
Similarly, a randomized clinical trial indicated reduction in the chlorhexidine group, and 0.4 catheter-related bloodstream infections per 1,000 catheters/day in the chlorhexidine group and 1.3 per 1,000 catheters/day in the polyurethane group $(p=$ 0.005 , IC 0.09-0.65). ${ }^{15}$

Regarding the dressing adhesiveness, a study showed that the time of permanence of the catheter over 5 days increases the risk of poor fixation of the dressing in more than five times and the risk of development of local reaction by the use of occlusive dressing in continuous contact with the skin in more than four times. ${ }^{28}$ In this context the literature shows a study describing that nonintact dressings increase the proliferation of microorganisms at the insertion site. .,29 $^{2}$ Therefore daily inspection and palpation to verify the integrity, adhesiveness, and saturation of chlorhexidine-impregnated gel dressings, as well as reviewing the need for maintaining the CVC, are essential strategies to ensure the safety of patients by preventing catheter-related infections. ${ }^{5,6,8,19,29,30}$

In the present study the subclavian and jugular veins were used in insertions of the same quantity of catheters; in $47 \%$ of the cases the catheters were inserted in each one of the veins, and in $6 \%$ the catheters were inserted in the femoral vein. In the literature the distribution of catheters varies among some studies. ${ }^{5,15,27} \mathrm{~A}$ national article points out the subclavian vein as the most used $(72.1 \%)$, while no catheter was inserted in the femoral vein. ${ }^{27} \mathrm{~A}$ multicenter study pointed out the subclavian vein as the most used (39.9\%), followed by the femoral (32.8\%) and jugular $(27.3 \%)$ veins. ${ }^{15}$

It is important to mention that the CVC insertion site may influence the risk of infections related to this device, therefore the Centers for Disease Control and Prevention (CDC, 2011) recommend avoiding the femoral vein for insertion of short-term catheters, as this site is associated with a higher level of CVC colonization in comparison to the subclavian and jugular veins. In relation to infection control, the subclavian vein is indicated for catheter insertion. ${ }^{5}$

In this same direction Pedrolo et al. (2013) conducted an integrative review and found that the internal jugular vein presents higher risk of infection when compared with the subclavian vein due to its proximity to the upper airways and the difficult local immobilization. ${ }^{26}$ 
Regarding the durability of the dressing and the place of insertion of the catheter, the present study found that unscheduled changes were more frequent when the catheter was inserted in the subclavian vein, reaching $49 \%$ (41) of the changes. On the other hand, a smaller number of changes of catheters inserted in the jugular vein and a larger number of changes in the accesses via femoral vein, followed by the subclavian vein, was observed in another study. ${ }^{16,31}$

The dressings used as CVC covers were designed for skins that undergo a series of conditions, such as movements, temperature changes, perspiration, and external moisture. ${ }^{3,29}$ However it was observed in the study development that not all situations are described in the literature.

The assessment of the reasons for changes in all insertion sites revealed that $52 \%$ (43) of the unscheduled changes occurred due to loosen dressings, a fact that may be associated with intrinsic and extrinsic factors to the patient, such as skin characteristics (for example, oily skin); diaphoresis; and also the fact that the dressing may have been wet during bathing, showing the importance of protecting the dressing during bed baths.

The mean time of permanence of the dressing in the present study was 3.04 days. The mean number of dressings used per patient was 3.1, a quantity that may be considered high in comparison with the mean time of permanence of the CVC, that is, 8.6 days. This finding is corroborated based on the fact that 83 of the 95 dressing changes were unscheduled, that is, occurred before seven days, the time that chlorhexidine-impregnated gel dressings may be maintained.

A randomized clinical trial testing chlorhexidine and transparent polyurethane film dressings pointed out that having more than two dressing changes due to detachment is associated with three times more catheter-related infections $(p=0.023$ with level of significance lower than $5 \%)$. The authors identified that as of the second change such increase may reach 12 times the number of these infections $(p=0.0001$ with level of significance less than $5 \%$ ), that is, the higher the number of changes due to loosening the higher the number of occurrences of catheter-related bloodstream infections. ${ }^{17}$ The univariate analysis conducted according to the Cox model of this clinical trial showed an association between detached dressings and colonization of the intravascular catheter. ${ }^{17}$

In this same perspective a national study demonstrated that more than two changes of chlorhexidine-impregnated gel dressings increases in more than nine times the risk of poor fixation of the dressing, presenting $p=0.0061$ with a level of significance of $5 \%{ }^{28}$ Inadequate fixation results in spontaneous detachment of the dressing, a factor the leads to its change. ${ }^{28}$

The dressing is intended to be occlusive, therefore it should be maintained totally fixed to the skin of the patient to protect the insertion site of the catheter, provide stability to the device, and reduce the risk of contamination by microorganisms. ${ }^{17,29}$
On the other hand, the present study pointed out that only a few cases allowed the chlorhexidine-impregnated gel dressing to be maintained for seven days, as it is recommended in the literature.

The number of CVC-related bloodstream infections decreased after the implementation of essential insertion and maintenance procedures called bundles. Insertion bundles consist in: proper hand hygiene; maximum protection barriers during catheter insertion; use of a checklist during the insertion; skin antisepsis with chlorhexidine; optimization of the choice of the insertion site; use of catheter insertion kits with the materials required for insertion; and training of physicians, nurses, and other health professionals on measures to prevent catheter-related infections. ${ }^{6,30,32,33}$

Regarding the maintenance bundles, the following measures stand out: hand hygiene; daily assessment of the catheter and insertion site; daily assessment of the dressing and execution of change as recommended; use of a kit to change the dressing; removal of the catheter when there is no more indication for use; connections and hub-related care; reduced use of catheter connections; education and training in health for the entire team responsible for the insertion, care, and maintenance of the catheter; and training for patients and/or family members on CVC-related care. $6,30,32,33$

A before and after study on the implementation of a catheter-related infection prevention bundle showed that the mean time between the catheter insertion and onset of bloodstream infection was 11.3 days in the stage conducted without the use of the mentioned measures, and 13.4 days in the bundle intervention stage. ${ }^{32}$

Considering that dressing overchange is a risk factor for its colonization and catheter-related infections, the study suggests assessing the dressing integrity in the central catheter maintenance bundles. ${ }^{17}$

A study assessed the implementation of a CVC insertion and maintenance bundle that included dressing daily evaluation and care measures and measures related to the execution of changes when necessary. ${ }^{30}$ After the implementation of this bundle a decrease from three to less than one catheter-related bloodstream infection per 1,000 catheters/day was observed. The authors concluded that such results demonstrate an improvement in the quality of care provided to patients. ${ }^{30}$

Based on the results obtained and discussed in the present study the importance of nursing care related to changing central venous catheter dressings is emphasized, as these measures are essential in the prevention of catheter-related infections. However such care procedures should be conducted in conjunction with other prevention and maintenance measures. The whole health team involved in the direct care related to the CVC should receive training to execute such measures. Also, one of the items of the institutional bundle should be the assessment of dressings as a daily routine procedure. 


\section{CONCLUSIONS AND IMPLICATIONS FOR PRACTICE}

Chlorhexidine-impregnated gel dressings are recommended to be used for seven days, but the present study evidenced that dressings remained in the patients for this period only a few times, since the mean frequency of change was lower than the indication of use.

Dressing detachment in catheters inserted in the subclavian vein was the most frequent reason for unscheduled changes. The number of dressings used per patient exceeded the expectations in relation to the mean length of stay, as it was observed that the patient needs a higher number of dressings than the value recommended in the literature.

Therefore the incorporation of this technology in care should be weighted considering the financial cost to acquire chlorhexidine-impregnated gel dressings by health institutions.

Due to the scarcity of national studies assessing chlorhexidine-impregnated gel dressing changes, this study pointed out the need to conduct further research in Brazil, as well as comparisons with other types of dressings in order to find out which one would be the ideal for critical patients hospitalized in Brazilian health institutions, and others assessing its economic impact.

\section{LIMITATIONS}

The following situations and their justifications may be mentioned as limitations: skin characteristics of the Brazilian population, such as oily skin; region of the country where the study was conducted, which presents warm climate almost the whole year, contributing to excessive transpiration of patients despite the fact that the place of the study was a closed unit with controlled room temperature; wetness in the chlorhexidine-impregnated gel dressing that may occur during the bed bath; and the small size of the sample, which may have limited the conclusion.

These aspects were not controlled in the present study, and they may have influenced the occurrence of detachment of the chlorhexidine-impregnated gel dressings. It is recommended that they should be considered in the planning of future studies and in the incorporation of this dressing in the clinical practice.

\section{REFERENCES}

1. Nogueira LS, Koike KM, Sardinha DS, Padilha KG, Sousa RMC. Carga de trabalho de enfermagem em unidades de terapia intensiva públicas e privadas. Rev Bras Ter Intensiva [Internet]. 2013 Jul/Set; [cited 2016 Aug 23]; 25(3):225-32. Available from: http://www.scielo.br/scielo. php? script=sci_arttext\&pid=S0103-507X2013000300225\&nrm=iso. DOI: 10.5935/0103-507X.20130039

2. Gavin NC, Webster J, Chan RJ, Rickard CM. Frequency of dressing changes for central venous access devices on catheter-related infections. Cochrane Database Syst Rev [Internet]. 2016 Feb; [cited 2016 Aug 23]; 2:CD009213. Available from: http://www.ncbi.nlm.nih. gov/pubmed/26827714. DOI: 10.1002/14651858.CD009213.pub2
3. Ullman AJ, Cooke ML, Mitchell M, Lin F, New K, Long DA, et al. Dressing and securement for central venous access devices (CVADs): A Cochrane systematic review. Int J Nurs Stud [Internet]. 2016 Jul; [cited 2016 Aug 23]; 59:177-96. Available from: http://www.ncbi.nlm.nih.gov/ pubmed/27222463. DOI: 10.1016/j.jijnurstu.2016.04.003

4. Centers for Diseases Control and Prevention (CDC). Bloodstream Infection Event (Central Line-Associated Bloodstream Infection and noncentral line-associated Bloodstream Infection). [Internet]. Atlanta: Centers for Diseases Control and Prevention; 2017 [cited 2017 Feb 13]. Available from: https://www.cdc.gov/nhsn/pdfs/pscmanual/4psc_clabscurrent.pdf

5. O'Grady NP, Alexander M, Burns LA, Dellinger EP, Garland J, Heard SO, et al. Healthcare Infection Control Practices Advisory Committee. Guidelines for the prevention of intravascular catheter-related infections. Am J Infect Control [Internet]. 2011 May; [cited 2016 Aug 23]; 39(4 Suppl 1):1-34. Available from: http://www.ncbi.nlm.nih.gov/pubmed/21511081 DOI: 10.1016/j.ajic.2011.01.003

6. Ministério da Saúde (BR). Agência Nacional de Vigilância Sanitária. Medidas de Prevenção de Infecção Relacionada à Assistência à Saúde. Brasilia: Anvisa; 2017. [cited 2017 Apr 11]. 201 p. Available from: http:// portal.anvisa.gov.br/documents/33852/271855/Medidas+de+Preven $\%$ C3\%A7\%C3\%A30+de+Infec\%C3\%A7\%C3\%A3o+Relacionada+\% C3\%A0+Assist\%C3\%AAncia+\%C3\%A0+Sa\%C3\%BAde/6b16dab36d0c-4399-9d84-141d2e81c809

7. Safdar N, Maki DG. The pathogenesis of catheter-related bloodstream infection with noncuffed short-term central venous catheters. Intensive Care Med [Internet]. 2004 Jan; [cited 2017 Apr 11]; 30(1):62-7. Available from: http://www.ncbi.nlm.nih.gov/pubmed/14647886. DOI: 10.1007/ s00134-003-2045-z

8. Weeks KR, Hsu YJ, Yang T, Sawyer M, Marsteller JA. Influence of a multifaceted intervention on central line days in intensive care units: results of a national multisite study. Am J Infect Control [Internet]. 2014 Oct; [cited 2016 Aug 23]; 42(10):197-202. Available from: http://www. ncbi.nlm.nih.gov/pubmed/25239710. DOI: 10.1016/j.ajic.2014.06.003

9. Safdar N, O'Horo JC, Ghufran A, Bearden A, Didier ME, Chateau D, et al. Chlorhexidine-impregnated dressing for prevention of catheter-related bloodstream infection: a meta-analysis* . Crit Care Med [Internet]. 2014 Jul; [cited 2016 Aug 29]; 42(7):1703-13. Available from: http://www.ncbi. nlm.nih.gov/pubmed/24674924.DOI:10.1097/CCM.0000000000000319

10. Webster J, Gillies D, O'Riordan E, Sherriff KL, Rickard CM. Gauze and tape and transparent polyurethane dressings for central venous catheters. Cochrane Database Syst Rev [Internet]. 2011 Nov; [cited 2017 Apr 11]; 9(11):CD003827. Available from: http://www.ncbi.nlm. nih.gov/pubmed/22071809. DOI: 10.1002/14651858.CD003827.pub2

11. Bashir MH, Olson LK, Walters SA. Suppression of regrowth of normal skin flora under chlorhexidine gluconate dressings applied to chlorhexidine gluconate-prepped skin. Am J Infect Control [Internet] 2012 May; [cited 2016 Aug 29]; 40(4):344-8. Available from: http://www. ncbi.nlm.nih.gov/pubmed/21737178. DOI: 10.1016/j.ajic.2011.03.030

12. Pfaff $B$, Heithaus $T$, Emanuelsen $M$. Use of a 1-piece chlorhexidine gluconate transparent dressing on critically ill patients. Crit Care Nurse [Internet].2012 Aug; [cited 2017 Apr 11];32(4):35-40. Available from: http:// www.ncbi.nlm.nih.gov/pubmed/22855077. DOI: 10.4037/ccn2012956

13. $3 \mathrm{M}(\mathrm{tm})$. Tegaderm $(\mathrm{tm}) \mathrm{CHG}$ Chlorhexidine Gluconate I.V. Securement Dressings: All you need, all in one. 2014 [cited 2017 Aug 16]. Available from: http://multimedia.3m.com/mws/media/5015500/tegaderm-chgdressing-product-brochure.pdf

14. $3 \mathrm{M}(\mathrm{tm})$. Tegaderm(tm) $\mathrm{CHG}$ Chlorhexidine Gluconate Dressings Application and Removal Guide. Peace of Mind Matters. In: 3M Health Care, ed. Critical \& Chronic Care Solutions Division; 2013. Available from: http://multimedia.3m.com/mws/media/4915900/tegaderm-chgdressing-application-guide.pdf

15. Timsit JF, Schwebel C, Bouadma L, Geffroy A, Garrouste-Orgeas M, Pease S, et al. Chlorhexidine-impregnated sponges and less frequent dressing changes for prevention of catheter-related infections in critically ill adults: a randomized controlled trial. Jama [Internet]. 2009 Mar; [cited 2017 Jan 10]; 301(12):1231-41. Available from: http://www.ncbi.nlm.nih. gov/pubmed/19318651. DOI: 10.1001/jama.2009.376 
16. Timsit JF, Mimoz O, Mourvillier B, Souweine B, Garrouste-Orgeas M, Alfandari S, et al. Randomized controlled trial of chlorhexidine dressing and highly adhesive dressing for preventing catheter-related infections in critically ill adults. Am J Respir Crit Care Med [Internet]. 2012 Dec; [cited 2016 Oct 14]; 186(12):1272-8. Available from: http://www.ncbi. nlm.nih.gov/pubmed/23043083. DOI: 10.1164/rccm.201206-1038OC

17. Timsit JF, Bouadma L, Ruckly S, Schwebel C, Garrouste-Orgeas $\mathrm{M}$, Bronchard R, et al. Dressing disruption is a major risk factor for catheter-related infections. Crit Care Med [Internet]. 2012 Jun; [cited 2016 Sep 13]; 40(6):1707-14. Available from: http://www.ncbi.nlm.nih. gov/pubmed/22488003. DOI: 10.1097/CCM.0b013e31824e0d46

18. Shapey IM, Foster MA, Whitehouse T, Jumaa P, Bion JF. Central venous catheter-related bloodstream infections: improving postinsertion catheter care. J Hosp Infect [Internet]. 2009 Feb; [cited 2017 Jan 10]; 71(2):117-22. Available from: http://www.ncbi.nlm.nih.gov/ pubmed/19013680. DOI: 10.1016/j.jhin.2008.09.016

19. Marschall J, Mermel LA, Fakih M, Hadaway L, Kallen A, O'Grady NP, et al.; Society for Healthcare Epidemiology of America. Strategies to prevent central line-associated bloodstream infections in acute care hospitals: 2014 update. Infect Control Hosp Epidemiol [Internet]. 2014 Jul; [cited 2017 Apr 11]; 35(7):753-71. Available from: https://www.ncbi. nlm.nih.gov/pubmed/24915204. DOI: 10.1086/676533

20. Margatho AS. Ensaio clínico randomizado do uso do curativo gel de clorexidina para a prevenção da colonização do cateter venoso central em pacientes adultos críticos [tese]. Ribeirão Preto (SP): Escola de Enfermagem de Ribeirão Preto, Universidade de São Paulo; 2016.

21. Tereran NP, Zanei SSV, Whitaker IY. Qualidade de vida prévia à internação em unidade de terapia intensiva. Rev Bras Ter Intensiva [Internet]. 2012 Oct/Dec; [cited 2016 Oct 29]; 24(4):3416. Available from: http://www.scielo.br/scielo.php?script=sci arttext\&pid=S0103-507X2012000400008\&nrm=iso. DOI: 10.1590/ S0103-507X2012000400008

22. Marsilio NR, Silva D, Bueno D. Incompatibilidades medicamentosas em centro de tratamento intensivo adulto de um hospital universitário. Rev Bras Ter Intensiva [Internet]. 2016 Apr/Jun; [cited 2016 Oct 29]; 28(2):147-53. Available from: http://www.scielo.br/scielo. php?script=sci_arttext\&pid=S0103-507X2016000200147\&nrm=iso. DOI: $10.5935 / 0103-507 X .20160029$

23. Araujo TG, Rieder MM, Kutchak FM, Franco Filho JW. Readmissões e óbitos após a alta da UTI - um desafio da terapia intensiva. Rev Bras Ter Intensiva [Internet]. 2013 Jan/Mar; [cited 2016 Oct 29]; 25(1):32-8. Available from: http://www.scielo.br/scielo.php?script=sci_ arttext\&pid=S0103-507X2013000100007\&nrm=iso. DOI: $10.1590 /$ S0103-507X2013000100007

24. Pedreira LC, Brandão AS, Reis AM. Evento adverso no idoso em Unidade de Terapia Intensiva. Rev Bras Enferm [Internet]. 2013 May/Jun; [cited 2016 Oct 30]; 66(3):429-36. Available from: http://www.scielo.br/scielo. php?script=sci_arttext\&pid=S0034-71672013000300019\&nrm=iso. DOI: $10.1590 /$ S0034-71672013000300019
25. Favarin SS, Camponogara S. Perfil dos pacientes internados na unidade de terapia intensiva adulto de um hospital universitário. Rev Enferm UFSM [Internet]. 2012 May/Aug; [cited 2016 Oct 30]; 2(2):320-9. Available from: https://periodicos.ufsm.br/reufsm/article/ view/5178/3913. DOI: 10.5902/217976925178

26. Pedrolo E, Lazzari LSM, Oliveira GLR, Mingorance P, Danski MTR. Evidências para o cuidado de cateter venoso central de curta permanência: revisão integrativa. Rev Enferm UFPE On Line [Internet]. 2013 May; [cited 2016 Oct 31]; 7:4199-208. Available from: http://www. revista.ufpe.br/revistaenfermagem/index.php/revista/article/view/3236/ pdf_2626. DOI: 10.5205/reuol.4134-32743-1-SM-1.0705esp201313

27. Pedrolo E, Danski MTR, Vayego SA. Curativo de clorexidina e gaze e fita para cateter venoso central: ensaio clínico randomizado. Rev LatinoAm Enferm [Internet]. 2014 Spt/Oct; [cited 2016 Oct 31]; 22(5):764-71. Available from: http://www.revistas.usp.br/rlae/article/view/99293.DOI: 10.1590/0104-1169.3443.2478

28. Pedrolo E, Danski MTR, Vayego SA, Oliveira GLR, Boostel R. Infection, local reaction and poor fixation of dressings for central venous catheter. Acta Paul Enferm [Internet]. 2014 Jan/Feb; [cited 2016 Nov 1]; 27(1):63-8. Available from: http://www.scielo.br/scielo. php?script=sci_arttext\&pid=S0103-21002014000100013\&nrm=iso. DOI: 10.1590/1982-0194201400013

29. Jeanes A, Bitmead J. Reducing bloodstream infection with a chlorhexidine gel IV dressing. Br J Nurs [Internet]. 2015 Oct; [cited 2017 Mar 16]; 24(19):S14-9. Available from: https://www.ncbi.nlm.nih.gov/ pubmed/26496869. DOI: 10.12968/bjon.2015.24.Sup19.S14

30. Wheeler DS, Giaccone MJ, Hutchinson N, Haygood M, Bondurant $P$, Demmel $\mathrm{K}$, et al. A hospital-wide quality-improvement collaborative to reduce catheter-associated bloodstream infections. Pediatrics [Internet]. 2011; [cited 2017 Apr 11]; 128(4):e995-e1004; quiz e-7. Available from: http://www.ncbi.nlm.nih.gov/pubmed/21930547. DOI: 10.1542/peds.2010-2601

31. Timsit JF, Bouadma L, Mimoz O, Parienti JJ, Garrouste-Orgeas M, Alfandari $\mathrm{S}$, et al. Jugular versus femoral short-term catheterization and risk of infection in intensive care unit patients. Causal analysis of two randomized trials. Am J Respir Crit Care Med [Internet]. $2013 \mathrm{Nov}$; [cited 2017 Mar 16]; 188(10):1232-9. Available from: https://www.ncbi. nlm.nih.gov/pubmed/24127770. DOI: 10.1164/rccm.201303-04600C

32. Jeong IS, Park SM, Lee JM, Song JY, Lee SJ. Effect of central line bundle on central line-associated bloodstream infections in intensive care units. Am J Infect Control [Internet]. 2013 Aug; [cited 2016 Oct 31]; 41(8):710-6. Available from: http://www.ncbi.nlm.nih.gov/ pubmed/23394886. DOI: 10.1016/j.ajic.2012.10.010

33. Institute for Healthcare Improvement. How-to Guide:Prevent Central LineAssociated Bloodstream Infections (CLABSI). [Internet]. Cambridge: Institute for Healthcare Improvement; 2012. [cited 2016 Oct 31] Available from: http://www.chpso.org/sites/main/files/file-attachments/ ini_howtopreventcentrallineassociatedbloodstreaminfections.pdf

a Article extracted from the doctoral thesis "Ensaio clínico randomizado do uso do curativo gel de clorexidina para a prevenção da colonização do cateter venoso central em pacientes adultos críticos" (Registration NCT 02472158), financed by the Graduate Program in Fundamental Nursing Proex-Capes $2118 / 2012$. 